\title{
Corporate Culture and Geopolitics*
}

\author{
Jean-Marc de Leersnyder ${ }^{* *}$
}

\begin{abstract}
Geopolitics represents a privileged field for leading public players (the States themselves, government bodies, international organisations) and other bodies from the non-profit sector ( $N G O s$ ).

In the modern world, business has become one of the biggest contributors to geopolitics.

Corporate strategy is developed within what is now a reconfigured space. This reconfiguration is the result of three factors: the geopolitical situation, globalisation and the behaviour and conduct of international corporations themselves.

The commercial sphere is not separate to the political one. Geopolitics is the result of the games played out by all the leading players on the international scene. On this stage, neither states nor businesses can expect to play alone.
\end{abstract}

Keywords: Geopolitics; Geopolitics of Business; Market Economy; Foreign Trade Proliferation; Corporate Culture; Corporate Diplomacy; Globalisation

\section{The Market Economy and Geopolitics}

The period of significant international tension that we are currently witnessing, and the risk that the leading world power may become involved in a war, once again raises the issue as to the impact geopolitics can have on both the economy and corporate strategy. A certain type of traditionalism, or perhaps just plain short sightedness, tends to exclude companies from the geopolitical sphere, with the exception (and without doubt an important one) of the defence and oil sector.

From such a Manichaean viewpoint, geopolitics represents a privileged field for leading public players (the States themselves, government bodies, international organisations) and other bodies from the non-profit sector (NGOs). In such a scenario, companies should play no part and just simply suffer the consequences of the geopolitical situation without any opportunity to react, respond or have any say in the matter.

\footnotetext{
* Translated under authorization of the 'Defence Nationale', Paris, April 2003

** Professor of International Marketing, Associate Dean Executive MBA, HEC, Jouy en Josas (deleersnyder@hec.fr)
} 
In the modern world, business has become one of the biggest contributors to geopolitics in that it maintains its own rationale in the face of world problems. As a result, the results of the games involving its leading players, i.e. companies, firms and corporations, cannot fail but to have a noteworthy effect and great deal of influence on the overall geopolitical situation.

Two factors contributed to the confinement of geopolitics outside the boundaries of corporate strategy: firstly, disinterest on the part of companies themselves towards politics in general, and, secondly a lack of commitment in the marketplace by individual States.

Business has for a long time now tried to lead a sheltered existence outside the realms of geopolitical concerns as if the marketplace were a protected commercial space, an oasis of peace and prosperity, preserved from progress and geopolitical shocks. That is why it is not the habit of companies to study, or even try to find a way to anticipate, political or military developments, just as it is not in the habits of their managers to participate in such geostrategic games. The most classic reaction, when faced with a highly tense international situation, is generally just to sit back and wait or even simply to give in - if the company's assets (or worse still, its staff) are threatened. Economic and financial intelligence has managed to dominate proceedings for the last ten years or so but, all too often, has developed outside the realms of the so-called noble corporate functions (strategy, finance and marketing).

Since the downfall of Communism and the failure of planned economies, nations have always tried to disengage themselves from economic and trade operations. The geographical broadening of liberalism and the generalisation of privatisations, such as those in the strategic sectors of transport, energy or telecommunications, has made it seem as if international relations are governed by market law alone. Even military activity is being privatised with multinational companies springing up and, rather like mercenaries, supplying either the state or other parties. Outsourcing has become widespread practice in the defence business not only in rogue states but also apparently in structured and democratic countries ${ }^{1}$.

Market economy, the freedom of national states and free trade seem to be the cardinal virtues upon which the contemporary world builds. The historic coincidence of practically universal adherence to these three values accounts to a great extent for the acceleration in the process of breaking down world barriers, at least with regard to the period between the fall of the Berlin Wall and September 11, 2001. Since then, there appear to have been some signs of change; following September 11, the federal American State launched itself into saving the airline business, and the return to protectionism has now become a permanent threat. However, it must be noted how the trading of major agricultural products has been safeguarded from the phenomenon of generalization that governs free trade practices. The 2003 World Social Forum in Porto Alegre particularly stressed the demands of developing countries to do away with the protectionist and subsidybased systems so characteristic of both European and American agriculture.

This lack of commitment on the part of the State as the economically responsible party, is paradoxically accompanied by excessive zeal in surveillance by the public watchdogs over the financial and trading interests of companies the minute they start to do business outside their national territory. States act in some kind of great schizophrenic frenzy; they have no intention of being shareholders, selling cigarettes, matches, airline seats or telephone communications yet, at the same 
time, get very upset if a unilateral sanction impacts on the producers of Roquefort cheese or Dijon mustard in Europe, hormone fortified meat, or genetically modified bananas or cereals in the United States. It was the Clinton Administration which perfected the concept of economic safety, affirming that, "the defence of economic interests is at the very heart of the United States foreign policy" .

Geopolitics is fundamentally an analysis of territory, space and political arena. At least, this is how it came to be defined at the beginning of the twentieth century. An analysis of the relationship between space and strategy also deserves to be undertaken by the corporate world.

Corporate strategy is developed within what is now a reconfigured space. This reconfiguration is the result of three factors: the geopolitical situation, globalisation and the behaviour and conduct of international corporations themselves.

\section{Geopolitics Delimits Space}

Regional groups are consequently formed (like the European Union, at present made up of 15 countries, soon to become 25), and empires disappear (the Eastern block after the fall of Communism). In the future, a new bill on trade influence, and therefore a new slice of the market, will be the result of American intervention in the Far East. And the distribution of PSAs (Production Sharing Agreements) will suffer as a consequence. The effects on businesses will be enormous as these agreements, between an oil company and a state, give the company the rights to report the reserves controlled in this way in their financial statements, with all the imaginable implications for the stock exchange.

\subsection{Geopolitics as a Determining Factor in the Marketplace}

When Czechoslovakia was divided into two, world trade involving the Czech Republic and Slovakia increased by a calculable fixed amount during the night between December 311992 and the January 1 1993. In actual fact, a trade agreement between Prague and Bratislava obtained export status in that one night and was recorded as such by the WTO. Decolonisation (in the sixties), the dislocation of Yugoslavia and the USSR for example, led to the creation of a large number of new states. This 'proliferation of states' ${ }^{3}$ to fall back on an age-old saying, does not only affect the political balkanisation of some regions of the world. It also has far reaching consequences on the configuration of world markets, which go far beyond the largely anecdotal statistical impact on world trade. This is also an issue that by and large seems to have escaped the attention of economists. It is actually quite rare to read any analysis of the growth in world trade which makes any reference at all to this phenomenon. The Cold War split the trading universe up over a period of forty years. So much so that $\mathrm{GATT}^{4}$, which produced statistics on world trade, used to indicate the entire block of countries with planned economies in their own specific statistical section called 'Eastern Countries'.

Wars can give rise to new markets or cause them to disappear as they tend to rid themselves of demographic and economic data and instead be determined by geopolitical data. So what effects do conflicts have on markets? From the viewpoint of demand there is generally a concentration in demand for 
indispensable products. Demand tends to target less prestigious products and brands. From the point of view of supply, an informal sector begins to appear. Small businesses, small itinerant sales kiosks, short-term facilities, bargain tooters and second-hand markets, parallel imports, black market and contraband goods. Generally speaking, multinational companies, which are run more efficiently, gain market share at the expense of ruined local competitors. Economic sanctions, such as those imposed by the UN on Iraq (oil for food) favour the emergence of bargaining and triangular trade practices. Lastly the aftermath of war and subsequent reconstruction period generate new markets which are often huge and backed by associated financing.

\subsection{Economic Sanctions have an Impact on Corporate Strategies}

Economic sanctions are an important tool in foreign policy, one that lies halfway between diplomacy and the use of force. The effectiveness of these sanctions is widely debated. It is rightly emphasised that first and foremost they impact on the civil population, and the effect they have on businesses is undoubtedly minimal compared to the cost borne by both men and women. Nevertheless, businesses are still hostage to these sanctions, the nature of which and the practical effects arising from them being essentially economic/financial. We need to consider the different types of sanctions in greater detail and differentiate between those issued by the Security Council and those decided by individual states, between multilateral ones and unilateral ones. It is the latter type, and in particular embargoes, which have the greatest consequences on private trade transactions and, therefore, on the strategies of international corporations. What actually strikes you about these measures is their increasingly more extraterritorial nature. When a country such as the United States defines sanctions, it looks to involve other states. This is not only in order to increase their effectiveness, but also, from a rather more cynical viewpoint, to share the weight of the negative consequences amongst several countries and so avoid solely American businesses being penalised as a result.

A law such as the American D'Amato-Kennedy Law is a good example of the consequences of political decisions on trade. In the name of the fight against international terrorism and the defence of peace and international security, the D'Amato-Kennedy Law limits Iran's capabilities to exploit, extract, refine or transport its oil resources via oil pipelines.

The D'Amato Law sanctions foreign investments above 40 million dollars in Libya and Iran. Under pressure from the European Union the Americans have had to waive the application of this law outside the United States in the case of a French oil company.

Embargo decisions transform a political risk into a commercial risk through their impact on trade relations, and this occurs from the very moment in time when the chosen sanction in an international controversy is one of an economic nature.

Even if embargo is the most widely known form of economic sanction, in actual fact there are many others: the limiting of imports and exports; the freezing of assets abroad; an increase in customs duties; the breaking off of diplomatic relations; the refusal of visas; the blocking of credit; or even the refusal to grant airspace. The United States uses the weapon of economic sanctions extensively in its foreign policy. The American Congress estimates that American economic 
sanctions established over the four-year period (1997-2000) affected 61 countries, $42 \%$ of the world's population, and $19 \%$ of the world's export market. The United States has imposed unilateral economic sanctions approximately one hundred times since the end of the Second World War. The most famous, even now, are those involving the island of Cuba, and if the Helms-Burton Act is still used as an example, it is because there is a further dimension to its unilateral nature: its extra territorialism. The Cuban Liberty and Democratic Solidarity Act, better known under the name of the Helms-Burton Act, is a clear example of 'second degree boycotting': one State A trying to prevent citizens of another country B, who are resident abroad, from trading with a third State $\mathrm{C}$ or from investing there. By producing effects of extra territorialism, this American law has completely upset the rules governing both international law and the game of international competition. In the name of universal values such as democracy, the rights of mankind, the fight against terrorism or the prevention of the proliferation of arms of mass destruction, some States expect, through unilateral embargo decisions, to deny other States their right to participate in trade and economic exchange. The reasoning behind this extraterritorial application of sanctions is the fact that as soon as a business in a third country develops a flow of trade with a boycotted country, this will strengthen the country's ability to damage the interests of the country which decided on the sanction in the first place.

\section{Globalisation Creates New Spaces}

This is not the most suitable place to start getting into the depths of a debate on globalisation, or to add to an already long list of attempts at the definition of this phenomenon. Let us just remember though that what distinguishes globalisation from internationalisation (or more correctly inter-nationalisation) is really the fact that in the case of globalisation the nation state is no longer the relevant spatial entity. In other words, globalisation has generated new spaces within which the players, be they public or private entities, traditional or new entries, licit or illicit, etc., bring their own strategies into play and use them on a global basis. Besides being a way of bringing the nation state into discussion; globalisation is well and truly a real reconfiguration of space. The state's space remains, but is weakened by transfers of sovereignty or some elements of stately power (currency, taxation, customs rights, etc.) to new bodies. Similarly, it may be weakened through the rebuttal of the principle of territoriality of laws as a result of the influence played by Community (EEC) legislation or national decisions of enforcement deemed universal, such as the aforementioned economic sanctions.

Thus supranational spaces have come to see the light of day although their diversity prohibits calling them by a single name or concept (what do the European Union and Mercosur have in common?)

The creation of regional spaces in turn is linked to natural circumstances (geographic, linguistic and cultural proximity), to synergies between the production systems of the countries involved, but above all, to political designs for integration. The formation of such regional groupings, areas of free trade or economic union, constitutes for companies what economists refer to as the unexpected profits effect. These agreements lead to the creation of vast unified markets. With the formation 
of Mercosur, the Argentines, Brazil, Paraguay, Chile, Uruguay and Bolivia became real strategic mechanisms for enterprise. Through their trade agreements these countries form an area which groups together the theoretically top-performing economies in South America. It is because this group was so structured that business, and in particular the car manufacturing industry, decided to invest there. This same geographical space, without its trade agreements, would not have carried the same appeal. The existence of a common customs duty allows this group of 'small countries', in the interpretation of international economic theory, i.e. those countries whose demand does not influence international prices, to reach the decisive ranking of 'large country', whose variations in demand can potentially influence world trends. Globalisation also includes the capability of the players involved to move within new spaces, which are autonomous in respect to their own states, and where the rules of the game, and - individually - the rules of law founded on the principle of territoriality, are not enforced. Thus they move within new territories and autonomous spaces, such as the Internet, or cyberspace, which are independent from their own states. We are all aware of the difficulties involved in regulating and controlling Internet sites: but for enterprise and businesses, the Internet is a marvellous medium. It has permitted the development of e-business and in particular e-commerce. The bursting of the new economy bubble has not put a stop to e-business. It has simply amortized its excesses. Thanks to the Internet, for the very first time in the history of trade relations, we now have a response to the international market through an absolutely global technique. Up until now, techniques were being put in place to respond to an ever more global market. With the Internet, the tool has finally become proportionate to the problem faced: it is global.

Financial markets are also a terrain for 'non-territorial' manoeuvres, in which businesses deploy their own assets and their own ideas. But they are not alone: the uses that mafia organisations and terrorist organisations make of them through laundering and black market activities are only too well known.

\subsection{Foreign Trade Proliferation and Dissemination}

It is a known fact that growth in international economic relations is accompanied by a sharp rise in the power of intangible assets trading. This phenomenon of dematerialization of global trade encompasses the supply of transborder services, the sale of industrial and intellectual property, the flow of technology and, more generally speaking, virtual trading activities. This dematerialization of trade and the increasing intangible and virtual content of traded products, has greatly increased the ambit of what are termed 'sensitive products'. Through licensing, franchising and sub-tendering or outsourcing agreements, counter trade and offset agreements, the risk of undesired transfer of skills and technology increases alarmingly. Modern techniques of international trading are the generators of involuntary 'technological leaks'.

In matters of technological flow, the recent geopolitical situation (the end of the East-West disputes and the disorganisation of countries once developed within a state economy) has led to the appearance of a new form of 'trading'. Alongside the exchange of technology between developed countries and the transfers which are characteristic of the technological flow from developed countries towards 
developing ones, some new forms of transaction have arisen between emerging countries by way of dissemination and proliferation. We must expect that such a form of 'trading' will be extended to less 'sensitive' products than the strategic ones with which it began. The spreading of Viagra in developing countries is definitely emblematic of such a commercial approach.

Table 1: Methods of International Technology Transfer

\begin{tabular}{|l|l|l|}
\cline { 2 - 3 } \multicolumn{1}{c|}{} & $\begin{array}{l}\text { Developed } \\
\text { Countries }\end{array}$ & Emerging Countries \\
\hline $\begin{array}{l}\text { Developed } \\
\text { Countries }\end{array}$ & $\begin{array}{l}\text { Technology } \\
\text { exchange }\end{array}$ & Technology transfer \\
\hline $\begin{array}{l}\text { Emerging } \\
\text { Countries }\end{array}$ & $\begin{array}{l}\text { Inexistent } \\
\text { exchanges }\end{array}$ & $\begin{array}{l}\text { Dissemination and } \\
\text { proliferation }\end{array}$ \\
\hline
\end{tabular}

\subsection{Civilian Society and Economic Space}

The development of information technologies and progress in means of transport has brought about intensification in cultural flows, which contribute to the generation of international movements of opinion. Access by the public at large to the new media has favoured the creation of a public space without boundaries. This is the space that so-called 'civilian society' has occupied and made its own up to the point of acquiring a true and proper status on the international political, diplomatic and geopolitical scene. It will be observed that these organisations, which criticise the consequences of globalisation and attempt to fight it, are only able to make their own case known thanks to globalisation itself. The globalisation of means of communication has provided a world forum for anti-global organisations! It has been a well-known fact for a very long time now that every creature ends up rebelling against its creator.

The concept of civilian society, introduced by Hegel in 'Philosophy of Right' distinguishes between civilian and political life. At that time, civilian society tried to reduce the role of the state by taking political problems back into the civilian sphere, thus demonstrating that issues of general interest could not be regulated by public power alone. By way of a sort of deviation from this concept, today on the other hand, civilian society tries to demonstrate on the contrary that the common interest and the mechanisms linked to universal values should not be left to private interests and international businesses. It calls for greater regulation in view of the defence of values which are threatened by international businesses. By demanding more rules, civilian society is asking more of the state. Claims against genetically modified organisms and the protection of the environment have brought to light this paradox which is nothing other than a direct consequence of globalisation and of the disengagement of the state. The emergence of an internationalised mediadependent society, but above all an organised one equipped with a considerable reserve of followers, recruited mostly from among the younger generation of developed countries rather than the 'damned of the earth', gives rise to a new risk for businesses: that of becoming the target of a campaign of denigration or rather disinformation. Civilian society now exercises a powerful control over businesses: over the quality of their products, their production processes, their corporate code. 
If the state has its laws, civilian society has its own values and boycotting is to this society what legal and economic sanctions are to the state. A campaign of disinformation or a boycott may cost a business much dearer than a European Community fine or a loss of market share as a consequence of an embargo.

\section{Geopolitics of Business}

Corporations and businesses have also got to the point of defining a global space of their very own. For a long time they used a nation or country as the applicable point of aggregation to define markets or to segment the global market. It was convenient: national space and social and cultural space were all assimilated. A political organisation usually corresponds to a linguistic unit, an administrative structure, an educational system and a regulated space. With globalisation, the equation 'one country = one market' no longer has any strategic meaning, as businesses reason on the basis of transnational market segments in which consumers and customers with comparable expectations are grouped together without taking political borders into account. This has created more autonomous commercial spaces than political spaces, such as markets for 'Diasporas' or ethnic communities. Communitarianism is perhaps a political and social cure, but it also constitutes a market. The Hispanics represent a Pan-American market which the cosmetics firms, for example, know perfectly well how to 'read' and cater to with specific products and marketing. These strategies constitute counter powers and considerable financial weapons in the hands of businesses which can at times change the look of the world.

Let us recall the role of the western television networks during the fall of the Berlin Wall and let us look at how western consumer processes are transforming China. Solders have a habit of saying 'you cannot un-invent the atomic bomb'; we could add 'you cannot un-invent jeans'.

\section{Towards Corporate Diplomacy}

In the face of risks generated by geopolitical instability, enterprises can respond with two strategic activities: anticipation and negotiation. Anticipation consists in controlling the environment, watching over matters and economic intelligence. Negotiation is corporate diplomacy. Diplomats sometimes complain that political interests take second place to the principles of 'Realpolitik' (which are in fact elements of real economy). Similarly, businesses should equip themselves with diplomatic competences and skills. The weapon of economic diplomacy put in place by the state should be met by a diplomatic management, the limits of which are still to be defined.

This corporate diplomacy must be an integral part of international corporate communication. Businesses know how to get a message of a commercial nature to the consumer or a client. They must likewise be capable of addressing a message with a diplomatic content to a state or its representatives. In the first instance, a business is legitimately advertising, in the second, it is too often denied the right to be diplomatic. Lobbying, which has developed so much in Europe as a result of the 
impact of European Commission decisions on the business world, is a manifestation of this intense diplomatic activity by the business world. Lobbying may be entrusted to an internal group within the company or to a specialised office, or delegated within a pressure group to which the business belongs, which in turn will set up a lobbying study. Whatever the case, the aim is always the same: to dominate procedures where there is risk of regulations changing.

Lobbying was for a long time very unpopular in France. Nowadays, in Brussels, lobby groups are a permanent source of information for the Commission, which thus discloses its communications. It is estimated that there are in existence 3000 interest groups in Brussels and 500 corporate representatives, who are charged with this mission. A very welcome 'Lobbyist Charter' has even been created. International corporate diplomacy should not be limited to leading state players or international organisations. It should be extended to leaders from civilian society. The growing influence of consumer movements places a huge commercial risk on businesses. In order to minimise this risk, many businesses have decided to integrate their communication policies within the framework of sociallyresponsible and ethical codes of conduct.

Businesses which have moved production units to countries where labour costs are low are now eager to safeguard their image and avoid boycott campaigns, so that the fact that they make prisoners and children under fourteen years of age work in their factories will not be uncovered. In the face of the proliferation of enquiries, investigations, information and disinformation campaigns, all widely broadcast by the press, businesses adopt codes of good conduct and papers to reconcile ethics and business. In the face of these counter-powers, international businesses have invented a form of civil diplomacy, sometimes referred to as 'citizenship', or Corporate Social Responsibility, which allows them to take part in the social debate, with a procedural ambiguity that would have been defined as 'recovery' back in 1968. States invite one another to their games of competitiveness. In the face of this strategy of commercial and economic influence which the State puts into place to complete its defence and security policies, businesses must equip themselves with real diplomacy. International corporate strategy is reflected in geopolitics. There is only one single international environment. The commercial sphere is not separate to the political one. Geopolitics is the result of the games played out by all the leading players on the international scene. On this stage, neither states nor businesses can expect to play alone; but let us not lose sight of one essential element; in politics, contrary to what happens in economics, the risk in itself does not carry any performance prize. It is pure and simple loss for business.

\section{Notes}

1 Richard Bunégas: 'De la guerre au maintien de la paix: le nouveau business mercenaire'. Critique Internationale, Presses de Science Po, n²1, Autumn 1998, pp. 179-194.

2 Denis Lacorne: 'Où est l'interet national américain?', Critique Internationale, Presses de Sciences Po, n. 8, July 2000, pp. 97-116. 
${ }^{3}$ Pascal Boniface: 'La prolifération étatique: un défi stratégique majeur', Revue internationale et stratégique, n. 37, Spring 2000, pp. 59-64.

${ }^{4}$ GATT: General Agreement on Tariffs and Trade. 